\title{
Memory in humans is unaffected by central H1- antagonism, while objectively and subjectively measured sedation is increased
}

Citation for published version (APA):

van Ruitenbeek, P., Vermeeren, A., \& Riedel, W. J. (2010). Memory in humans is unaffected by central $\mathrm{H} 1$-antagonism, while objectively and subjectively measured sedation is increased. European Neuropsychopharmacology, 20(4), 226-235. https://doi.org/10.1016/j.euroneuro.2009.12.003

Document status and date:

Published: 01/04/2010

DOI:

10.1016/j.euroneuro.2009.12.003

Document Version:

Publisher's PDF, also known as Version of record

\section{Document license:}

Taverne

Please check the document version of this publication:

- A submitted manuscript is the version of the article upon submission and before peer-review. There can be important differences between the submitted version and the official published version of record.

People interested in the research are advised to contact the author for the final version of the publication, or visit the DOI to the publisher's website.

- The final author version and the galley proof are versions of the publication after peer review.

- The final published version features the final layout of the paper including the volume, issue and page numbers.

Link to publication

\footnotetext{
General rights rights.

- You may freely distribute the URL identifying the publication in the public portal. please follow below link for the End User Agreement:

www.umlib.nl/taverne-license

Take down policy

If you believe that this document breaches copyright please contact us at:

repository@maastrichtuniversity.nl

providing details and we will investigate your claim.
}

Copyright and moral rights for the publications made accessible in the public portal are retained by the authors and/or other copyright owners and it is a condition of accessing publications that users recognise and abide by the legal requirements associated with these

- Users may download and print one copy of any publication from the public portal for the purpose of private study or research.

- You may not further distribute the material or use it for any profit-making activity or commercial gain

If the publication is distributed under the terms of Article $25 \mathrm{fa}$ of the Dutch Copyright Act, indicated by the "Taverne" license above, 


\title{
Memory in humans is unaffected by central $\mathrm{H} 1$-antagonism, while objectively and subjectively measured sedation is increased
}

\author{
P. Van Ruitenbeek* ${ }^{*}$ A. Vermeeren ${ }^{1}$, W.J. Riedel ${ }^{2}$
}

Department of Neuropsychology and Psychopharmacology, Faculty of Psychology and Neuroscience, Maastricht University, The Netherlands

Received 28 July 2009; received in revised form 10 December 2009; accepted 12 December 2009

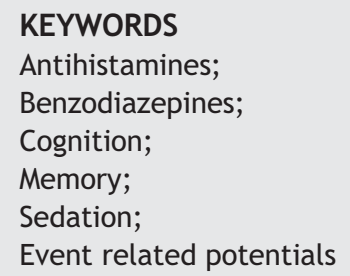

\begin{abstract}
Animal literature suggests an important role for histamine in memory. In humans, this hypothesis has been scarcely tested and results from studies that have addressed this are conflicting. Second, impaired memory performance may be secondary to sedation. This study aimed to determine whether a centrally active antihistamine impairs memory performance and to dissociate such effects from sedation. Eighteen healthy volunteers received single oral doses of dexchlorpheniramine $4 \mathrm{mg}$, lorazepam $1 \mathrm{mg}$ and placebo in a 3-way, double blind, crossover designed study. The active control lorazepam impaired episodic- and working memory performance and increased sedation, while dexchlorpheniramine only increased sedation.

(C) 2009 Elsevier B.V. and ECNP. All rights reserved.
\end{abstract}

\section{Introduction}

Animal studies indicate an important role for histamine in memory functioning. Decreasing histaminergic neurotransmission was found to impair memory (Alvarez and Ruarte, 2004; Dai et al., 2007; Acevedo et al., 2006). For example,

\footnotetext{
* Corresponding author. Department of Neuropsychology and Psychopharmacology Faculty of Psychology and Neuroscience, Maastricht University, P.O. Box 616, 6200 MD Maastricht, The Netherlands. Tel.: + 3143 3881026; fax: + 31433884560 .

E-mail address: p.vanruitenbeek@maastrichtuniversity.nl (P. Van Ruitenbeek).

1 Tel.: + 3143388 1952; fax: + 31433884560 .

${ }^{2}$ Tel.: + 3143388 4322; fax: + 31433884560 .
}

injection of the $\mathrm{H}_{1}$-antagonist pyrilamine into the amygdala was also found to impair memory functioning (Alvarez and Ruarte, 2004). Conversely, increasing histaminergic activity by pharmacologically blocking presynaptic $\mathrm{H}_{3}$-autoreceptors has been found to improve memory performance (Bacciottini et al., 2001; Zarrindast et al., 2008,). $\mathrm{H}_{3}$-antagonists have therefore attracted the attention of pharmaceutical companies as potential cognition enhancers.

However, the role of histamine in human memory is unclear. No studies are published on the cognition enhancing effects of histamine in humans, as the development of $\mathrm{H}_{3}$-antagonists for use in humans is slow. In addition, studies in which histamine functioning was decreased using $\mathrm{H}_{1}$-antagonists in humans have only occasionally assessed memory functions. Of those that did a majority found no significant effects on memory (De 
Brabander and Deberdt, 1990; Patat et al., 1994; Theunissen et al., 2004; Verster et al., 2003; Vuurman et al., 2004). A few investigators report significant impairments on memory performance (Gevins et al., 2002; Hindmarch and Shamsi, 2001; Volkerts et al., 1992; Vuurman et al., 1994). However, these effects may have been a by-product of their effects on arousal or attentional functions as they also induced sedation and psychomotor impairment (Curran, 2000).

Only three studies were specifically designed to distinguish between the sedative and memory impairing effects of antihistamines (Curran et al., 1998; Turner et al., 2006; Van Ruitenbeek et al., 2008). None of them found impairing effects on memory. Curran et al. (1998) showed that lorazepam and scopolamine significantly impaired psychomotor and memory performance, whereas diphenhydramine only affected psychomotor performance. Yet, results showed that the doses used were not equipotent with respect to their sedative and psychomotor effects: effects of diphenhydramine were relatively weak. It is possible therefore that the memory tests were not sufficiently sensitive to detect any weak amnestic effects of diphenhydramine. Turner et al. (2006) failed to find effects of increasing doses of diphenhydramine on word recall, but learning took place before drug administration. Any effects on encoding and consolidation could therefore not be measured. Finally, Van Ruitenbeek et al. (2008) failed to find effects of dexchlorpheniramine on word learning and recall. Yet, the test was administered 4 hours after drug intake, which may have been too late to detect any effects on memory, as the effects on psychomotor performance had already returned to baseline at that time. In sum, inappropriate timing of testing, and use of low doses or insensitive measures to detect weak effects may have obscured effects of $\mathrm{H}_{1}$-antagonists on memory functions.

The aim of the present study was to determine if a selective $\mathrm{H}_{1}$-antagonist, dexchlorpheniramine $4 \mathrm{mg}$, has effects on sensitive measures of memory performance and sedation during time of peak impairment of psychomotor functions. Therefore, we assessed its effects on memory and cortical activity between 1.5 and $2.5 \mathrm{~h}$ after administration (Van Ruitenbeek et al., 2008). Effects were compared to those of placebo and the benzodiazepine lorazepam (1 mg p.o.). The latter was included as an active control treatment for its known sedative and amnestic effects when given at a high dose (Curran et al., 1998; Mintzer and Griffiths, 2003; Turner et al., 2006; Vermeeren et al., 1995).

Effects on memory were assessed using measures of performance and cortical activity during a word learning task and an n-back task, which are sensitive to drug effects (File and Lister, 1982; Gevins et al., 2002; Riedel and Van Praag, 1995; Vermeeren et al., 1995). Since electroencephalogram (EEG) data can complement behavioural data (Gevins et al., 2002; Theunissen et al., 2006), we also measured event related potentials (ERP) and EEG power during task performance. The P300 ERP component is associated with memory processing (Polich, 2007). In a word learning task, correctly recalled words are found to be associated with larger P300 amplitudes recorded at the time of initial encoding than words that were not recalled (Friedman and Johnson, 2000; Otten and Donchin, 2000). In an n-back task, P300 amplitude was found to decrease with increasing memory load (Watter et al., 2001). So, to determine drug effects on memory we determined P300 amplitudes during encoding in the word learning task and during the n-back task. It was expected that amnestic drug effects would decrease mean P300 amplitude in both tasks.

To assess drug effects on arousal, changes in EEG energy spectra in the delta $(1-4 \mathrm{~Hz})$, theta $(4-8 \mathrm{~Hz})$, alpha $(8-12 \mathrm{~Hz})$ and beta $(12-30 \mathrm{~Hz})$ frequency ranges were recorded (Borbely, 1982; Galliaud et al., 2008; Griffiths et al., 1991). Both antihistamines and benzodiazepines have previously been found to induce changes in power in the alpha and theta band (Ebert et al., 2000; Greenblatt et al., 2000; Ramaekers et al., 1992; Saletu et al., 1986; Sannita et al., 1996). Finally, drug effects on arousal were also evaluated subjectively using series of visual analogue rating scales (Bond and Lader, 1974).

To determine whether any effects of dexchlorpheniramine on measures of memory are secondary to its sedative effects, changes in arousal and memory following dexchlorpheniramine and lorazepam were compared, using calculation of effect sizes.

\section{Experimental procedures}

\subsection{Subjects}

Eighteen healthy right handed subjects (nine males) between 18 and 45 years (mean \pm SE: $24.2 \pm 1.7$ years) were recruited by means of advertisements in local newspapers and were paid for their participation. Subject's health was screened using a medical history questionnaire and a physical examination, including a 12-lead electrocardiogram, blood chemistry and haematology, and urinary tests for pregnancy and drugs of abuse (amphetamine, benzodiazepine, cocaine, opiates, cannabis and methamphetamine). Exclusion criteria were a significant history or presence of any mental or physical disorder; gastrointestinal, hepatic, renal, cardiovascular or neurological. Also, drug abuse, a body-mass index outside the limits of 18 and $28 \mathrm{~kg} / \mathrm{m}^{2}$, blood pressure outside the limits of 100 and $150 \mathrm{Hg}$ systolic and 60 and $90 \mathrm{Hg}$ diastolic and drinking more than 20 standard alcoholic consumptions per week or 5 beverages containing caffeine per day were regarded as exclusion criteria. For women, pregnancy and lactation were also regarded as exclusion criteria. No drugs or medication, except oral contraceptives, aspirin and acetaminophen, were allowed to be taken from a week before the first test-day until the end of the study. Smoking and the use of caffeine were prohibited on test-days and the use of alcohol from 24 hours before and during each test-day. Subjects were allowed to have breakfast at home before 7:30 am, i.e. at least $3 \mathrm{~h}$ before drug intake.

All subjects received written information about the study procedures and were given the opportunity to ask questions. They signed an informed consent form prior to enrolment. The study was approved by the Ethics committee of Maastricht University and University Hospital Maastricht and carried out in accordance with the World Medical Association Declaration of Helsinki and its amendments (World-Medical-Association, 1964).

\subsection{Study design and treatments}

The study was conducted according to a double blind, placebocontrolled, 3-way crossover design. Treatments were single oral doses of dexchlorpheniramine $4 \mathrm{mg}$ and lorazepam $1 \mathrm{mg}$ (all immediate release formulations) and placebo and were spaced apart by a washout period of at least 4 days. Oral doses of dexchlorpheniramine produce peak plasma concentrations between 1.5 and $3 \mathrm{~h}$ after administration (Simons et al., 1994; Wiech and Martin, 1982) and lorazepam between 2 and $5 \mathrm{~h}$ (Busto et al., 2000; Greenblatt, 1981). The order of treatment was counterbalanced across subjects. 


\subsection{Procedure}

Subjects were individually trained to perform all tasks on two separate occasions within two weeks prior to their first treatment day. On treatment days subjects arrived at the University at 9:00 am. Between 9:00 am and 9:30 am the inclusion and exclusion criteria were checked. At 10:30 am the study medication was ingested and the tests were performed between 12:00 am and 1:00 pm i.e. around $T_{\max }$ for both treatments. The battery consisted of a word learning task, an $n$-back task and subjective alertness and was performed in this order. In addition, objective evaluations of alertness were obtained during word learning task performance.

\subsection{Performance assessments}

\subsubsection{0-words learning task}

The 30-words learning task (WLT-30) is an adapted version of Rey's Auditory Verbal Learning Test assessing immediate and delayed free recall, and recognition of verbal material.(Rey, 1964; Riedel et al., 1999). Thirty mono-syllabic nouns and adjectives are presented on a computer screen for $1000 \mathrm{~ms}$ at a rate of 1 per $2 \mathrm{~s}$. Subjects were instructed to memorize them and to recall as many words as possible when the presentation ends. This procedure is repeated three times, with the same words presented in the same sequence. The number of words correctly recalled during each trial is the "immediate recall score". After a 45 min delay subjects are requested again to recall as many words as possible. The number of words correctly recalled is the "delayed recall score". To correct for failures in initial acquisition, delayed recall is also scored as percentage of the third immediate recall score (relative recall). Finally, subjects are presented a series of 60 words on a computer screen that include the 30 words from the original list and 30 comparable but new words. Subjects are asked to indicate as quickly as possible whether the presented words are from the original list or not by pressing one of two buttons. The number and speed of correct responses are recorded as the recognition score and recognition time (ms), respectively. In addition, during the word learning phase EEG was recorded from which the P300 (WLT-P300) amplitude was extracted as a measure of encoding. Separate parallel word lists were used on the different test-days. All words occur highly frequent in the Dutch language and were acquired early in life. In addition, all words were carefully selected, such that all lists were equally difficult and with an overall similar emotional valence (Riedel et al., 1999). A pilot study in 300 students did not show any differences in list difficulty.

\subsubsection{N-back task}

The $n$-back task was based on descriptions provided in the paper by Braver et al. (1997) and Veltman et al. (2003) and was used to assess working memory performance. In this task subjects are required to monitor a series of letters presented in the centre of a computer screen, and to respond whenever a letter is presented that is the same as the letter presented one, two or three trials previously (i.e. 1-back, 2-back and 3-back, respectively). In the fourth (control) condition subjects have to press a button as fast as possible whenever they detected a target letter (e.g. X; 0-back). Letters are presented at a rate of 1 per 2 seconds. In this study subjects completed blocks consisting of 0-, 1-, 2-, or 3-back trials. Each block was repeated three times in pseudorandom order. Within each block 21 stimuli were presented, including 3 or 4 targets, totalling 11 targets per $n$-back level. Percentage and speed of correct responses were recorded per $n$-back level. In addition, the P300 (nback-P300) amplitude was measured on all target-trials and is an indicator of processing capacity related to comparing stimuli (Watter et al., 2001).

\subsubsection{Subjective alertness}

Subjective alertness was assessed using a series of 16 visual analogue scales of $100 \mathrm{~mm}$. These provide three factors which are analytically defined summary scores for 'alertness', 'contentedness', and 'calmness' (Bond and Lader, 1974) of which alertness was of main interest.

\subsection{EEG measurements}

During performance on the WLT-30 and n-back task EEG activity was recorded by means of an electrocap from an array of 32 electrodes from the standard 10-20 system (Jasper, 1957). All electrodes were filled with electrode-gel and were referenced to the mastoid electrodes both left and right. The FPz electrode was used as ground electrode. Horizontal EOG was recorded using electrodes attached to the outer canthi of the eyes and vertical EOG was recorded from electrodes attached above and below the left or right eye and in line with the pupil when the subject looks straight ahead.

All electrode impedances were kept below $5 \mathrm{k} \Omega$. Signals were amplified using Neuroscan Synamps amplifiers and collected using neuroscan software. All signals were sampled at a $1000 \mathrm{~Hz}$ and filtered online using a $100 \mathrm{~Hz}$ low-pass filter and a $0.1 \mathrm{~Hz}$ high-pass filter.

\subsubsection{Signal analysis}

Continuous signals obtained during the performance on the n-back task and WLT-30 were epoched in 1100 ms sweeps starting $100 \mathrm{~ms}$ before stimulus presentation. EEG was corrected for vertical and horizontal eye movements according to a procedure by Semlitsch et al. (1986). The interval between sweep onset and stimulus served as baseline. EEG epochs were filtered off-line using a $1.0 \mathrm{~Hz}$ high-pass filter and a $30 \mathrm{~Hz}$ low-pass filter for both WLT-30 and n-back task. Sweeps containing artefacts exceeding +75 or $-75 \mu \mathrm{V}$ were rejected. For the n-back task all trials, in which the target occurs, were used to calculate averages, and for the WLT30 all trials in which stimuli were presented during the immediate recall were used. The averages were calculated by averaging the data point by point.

For both the n-back task and the WLT-30 the amplitude of the P300 component was determined at the $\mathrm{Cz}$ electrode site. It was decided to determine the $\mathrm{P} 300$ amplitude in both tasks only at the $\mathrm{Cz}$ electrode site for two reasons. First, grand averages were calculated by averaging all epochs for the respective tasks. Inspection of the grand averages indicated that the P300 could most clearly be determined at the $\mathrm{Cz}$ electrode site. Second, P300 peak amplitudes were determined within a relatively small time-window; between 228 and 342 ms for the WLT-P300 and between 230 and 470 for the nback-P300 task as determined by a visual inspection of the peak latency of the grand average of the P300 for both tasks separately. Due to the presence of a large peak around $150 \mathrm{~ms}$ after stimulus presentation and because the P300 does not peak at the same moment at every electrode site, applying the same window would lead to many false peak amplitude data, i.e. P150 amplitudes.

The power $\left(\mu \mathrm{V}^{2}\right)$ of the delta $(1-4 \mathrm{~Hz})$, theta $(4-8 \mathrm{~Hz})$, alpha $(8-$ $12 \mathrm{~Hz})$ and beta $(12-30 \mathrm{~Hz})$ frequency bands was measured during the presentation of the words in the WLT-30 and were calculated by means of a fast Fourier transformation of the means of the midline electrodes ( $\mathrm{Fz}, \mathrm{Cz}$ and $\mathrm{Pz}$ ). These were taken as dependent variables and indicators of cortical activity and sedation.

\subsection{Statistical analysis}

First, all variables were screened for normality of the distributions. There were no indications of non-normal distributions. Subsequently, the immediate recall scores were analyzed according to a $3 \times 3$ two-factorial model with Treatment (dexchlorpheniramine, lorazepam, and placebo) and Trial (1, 2 and 3) as within subject factors using Analysis of Variance for repeated measures. The WLT-P300 amplitude following the presentation of words was averaged across all three trials and was analyzed for effects of Treatment using Analysis of Variance for repeated measures with Treatment as 
factor. The delayed recall score was similarly analyzed for effects of Treatment using Analysis of Variance for repeated measures with Treatment as factor.

For the $n$-back task the data were analyzed using a $3 \times 4$ twofactorial model with Treatment and Memory Load $(0,1,2$ and 3back) as within subject factors. For both tasks, if overall F-tests indicate significant main effects or interactions $(p<0.05)$, the data were further analyzed using two drug-placebo contrasts. Effects of Trial in the WLT-30 and Memory Load in the n-back task were analyzed using polynomial contrasts.

The power of the delta, theta, alpha and beta frequency bands were separately analyzed using a $3 \times 3$ two-factorial model with Treatment (dexchlorpheniramine, lorazepam, and placebo) and Electrode $(\mathrm{Fz}, \mathrm{Cz}$, and $\mathrm{Pz})$ as within subject factors.

Effect sizes of lorazepam and dexchlorpheniramine were calculated for all dependent variables. The effect sizes, expressed as Dunlap's $d$ (Dunlap et al., 1996), were calculated using the formula: $d=t_{\mathrm{c}}[2 / 1(1-r) / n]^{1 / 2}$ where $t_{\mathrm{c}}$ corresponds to the $t$-value of a dependent samples t-test between means of a dependent variable from two treatment groups. The $r$ corresponds to the correlation across pairs of measures and $n$ equals the numbers of subjects.

All data were analyzed using SPSS for Windows (version 12.0.1).

\section{Results}

\subsection{Missing data}

Analyses of the EEG frequency band power were performed on 17 subjects, because data from one subject showed extremely large (i.e. $>2$ standard deviations) delta frequency values and was therefore considered an outlier.

\subsection{Performance}

\subsubsection{0-words learning task}

Mean $( \pm$ SEM) immediate and delayed recall scores for separate treatments are shown in Fig. 1. There were significant main effects of Trial and Treatment on immediate recall scores $(F(2,16)=84.5, p<0.01$ and $F(2,16)=7.7, p<0.01$,

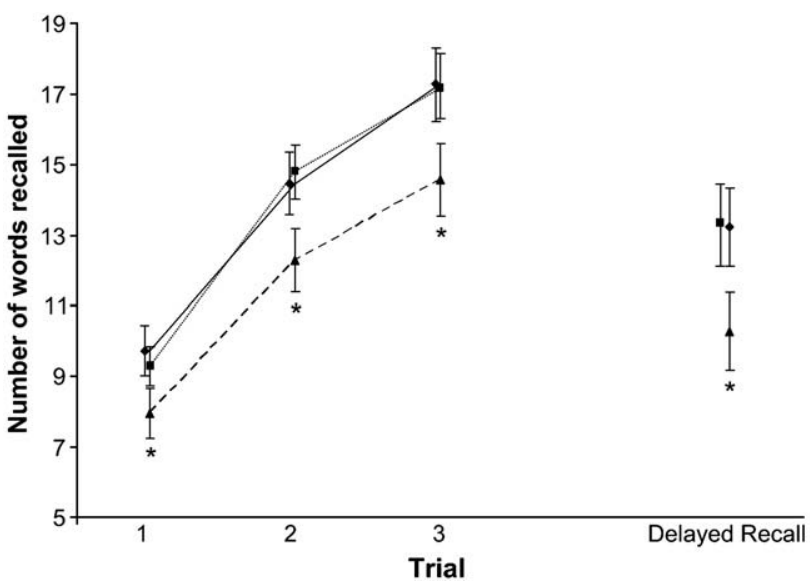

Figure 1 Performance on word learning. Mean $( \pm$ SEM) number of words recalled in three immediate recall trials and a delayed recall trial for the treatments separately. ${ }^{*}$ Indicates a significant $p<0.05$ difference in number of words recalled when compared with placebo. respectively). Overall, the number of words recalled increased linearly over consecutive trials $(F(1,17)=170.1, p<0.01)$. However, fewer words were recalled after lorazepam as compared with placebo $(F(1,17)=12.9, p<0.01)$. The effects of lorazepam were significant in each immediate recall trial $(F s(1,17)=6.0,8.7$ and 9.6, and $p s<0.03,0.01$ and $p<0.01$, for trials 1,2 and 3 , respectively). There was no difference in immediate recall scores between dexchlorpheniramine and placebo $(F(1,17)=2.7, p=0.12)$.

There were also significant differences between treatments in delayed recall scores $(F(2,16)=6.1, p<0.01)$, but not in the relative recall $(F(2,16)=1.6, p=0.24)$. Delayed recall was impaired after lorazepam $(F(1,17)=10.8, p<0.01)$, but not after the administration of dexchlorpheniramine.

In line with the above, there were significant differences between treatments in speed and accuracy of recognition ( $F$ $(2,16)=21.4, p<0.01$ and $F(2,16)=5.27, p<0.02$, respectively), which were due to the impairing effects of lorazepam ( $F$ $(1,17)=23.6, p<0.01$ and $F(1,17)=10.0, p<0.01$, respectively) (Table 1).

\subsubsection{N-back task}

Speed and accuracy in the n-back task were significantly affected by Memory Load $(F(3,15)=24.6, p<0.01$ and $F(3,15)=$ $11.5, p<0.01$, respectively). The reaction times and number of errors increased when the Memory Load increased.

Treatment effects on performance in the n-back task differed significantly as measured by reaction time $(F(2,16)=$ 7.1, $p<0.01$ ) and approached significance as measured by accuracy $(F(2,16)=3.1, p<0.07)$. Compared with placebo, lorazepam significantly increased reaction time $(F(1,17)=$ 13.5, $p<0.01)$ and decreased the percentage of correct responses $(F(1,17)=6.5, p<0.02)$, while dexchlorpheniramine did not. There was no significant interaction between Treatment and Memory Load (Table 2).

\subsubsection{Subjective alertness}

Subjective ratings of alertness differed significantly between treatments $(F(2,16)=7.8, p<0.01)$. Mean $( \pm$ SEM) alertness scores decreased significantly from $65.5( \pm 5.0)$ after placebo to $49.3( \pm 4.3)$ after dexchlorpheniramine and to $40.6( \pm 4.4)$ after lorazepam $(F s(1,17)=7.9$ and 16.6, $p=0.01$ and $p<0.01$, respectively).

\subsection{EEG measurements}

\subsection{1. $\mathrm{P} 300$}

The WLT-P300 amplitude during word learning (Fig. 2) differed significantly between treatments. $(F(2,16)=5.6$,

Table 1 Mean $( \pm$ SEM) reaction time and accuracy as measures of word recognition performance after each treatment. *Indicates significant $(p<0.05)$ drug-placebo contrasts.

\begin{tabular}{llll}
\hline & Placebo & $\begin{array}{l}\text { Dexchlorpheniramine } \\
4 \mathrm{mg}\end{array}$ & $\begin{array}{l}\text { Lorazepam } \\
1 \mathrm{mg}\end{array}$ \\
\hline $\begin{array}{l}\text { Reaction time } \\
\text { (ms) }\end{array}$ & $682(22)$ & $681(21)$ & $778(29)^{*}$ \\
$\begin{array}{l}\text { Accuracy (\%) } \\
85(2)\end{array}$ & $82(5)$ & $78(2)^{*}$ \\
\hline
\end{tabular}


Table 2 Mean $( \pm$ SEM) reaction time, accuracy and P300 amplitude as measures of performance on the n-back task after treatment with dexchlorpheniramine $4 \mathrm{mg}$ (D4), lorazepam $1 \mathrm{mg}$ (L1) and placebo.

\begin{tabular}{|c|c|c|c|c|c|c|}
\hline & Placebo & $\begin{array}{l}\text { Dexchlorpheniramine } \\
4 \mathrm{mg}\end{array}$ & $\begin{array}{l}\text { Lorazepam } \\
1 \mathrm{mg}\end{array}$ & $\begin{array}{l}\text { Main effect of } \\
\text { treatment }\end{array}$ & $\begin{array}{l}\text { D4 mg vs. } \\
\text { placebo }\end{array}$ & $\begin{array}{l}\text { L1 mg vs. } \\
\text { placebo }\end{array}$ \\
\hline & & & & $p$ & $p$ & $p$ \\
\hline Reaction time (ms) & & & & 0.006 & 0.456 & 0.002 \\
\hline 0-back & $342(7.3)$ & $351(8.0)$ & $378(11.3)$ & & & \\
\hline 1-back & $362(8.7)$ & $372(8.9)$ & $395(14.2)$ & & & \\
\hline 2-back & $396(14.9)$ & $401(14.3)$ & $444(16.3)$ & & & \\
\hline 3-back & $403(17.0)$ & $416(17.2)$ & $431(13.0)$ & & & \\
\hline Accuracy (\%) & & & & 0.071 & 0.474 & 0.021 \\
\hline 0-back & $95.3(.01)$ & $94.2(.02)$ & $93.8(.01)$ & & & \\
\hline 1-back & $96.3(.01)$ & $96.4(.01)$ & $96.1(.01)$ & & & \\
\hline 2-back & $95.2(.01)$ & $94.7(.01)$ & $91.4(.02)$ & & & \\
\hline 3-back & $93.3(.01)$ & $92.7(.01)$ & $87.8(.02)$ & & & \\
\hline Nback-P300 amplitude $(\mu \mathrm{V})$ & & & & 0.397 & 0.229 & 0.244 \\
\hline 0-back & $12.3(3.8)$ & $12.1(4.6)$ & $11.5(6.6)$ & & & \\
\hline 1-back & $14.1(5.0)$ & $13.4(5.0)$ & $13.1(3.9)$ & & & \\
\hline 2-back & $11.8(3.9)$ & $9.4(3.5)$ & $9.9(4.9)$ & & & \\
\hline 3-back & $8.6(4.2)$ & $8.8(3.5)$ & $8.6(4.6)$ & & & \\
\hline
\end{tabular}

$p<0.01)$. Lorazepam decreased the amplitude $(F(1,17)=9.7$, $p<0.01$ ), but dexchlorpheniramine did not.

Nback-P300 amplitude during performance in the n-back task decreased with increased memory load $(F(3,15)=12.4$, $p<0.01$ ), but did not differ between treatments. There was no significant interaction between Treatment and Memory Load $(F(6,12)=1.3, p=0.34)$ (Table 2$)$. For reasons previously mentioned, other electrode sites were not analyzed. Nevertheless, visual inspection of the data on the $\mathrm{Fz}, \mathrm{Cz}$ and $\mathrm{Pz}$ electrode sites suggested that this pattern did not differ between electrodes.

\subsubsection{Frequency band power}

There were significant or nearly significant differences between treatments in alpha $(F(2,15)=11.6, p<0.01)$ and

\section{WLT-P300}

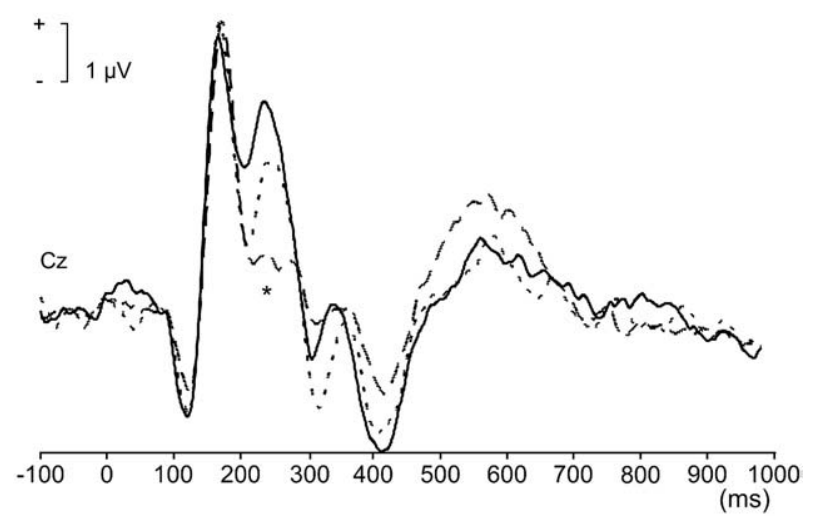

Figure 2 ERP waveform during word learning. The ERP waveform during word learning after the administration of dexchlorpheniramine $4 \mathrm{mg}$, lorazepam $1 \mathrm{mg}$ and placebo. Words were presented at $0 \mathrm{~ms}$. *Indicates a significant $(p<0.05)$ difference in peak amplitude when compared with placebo. theta $(F(2,15)=3.1, p<0.08)$ power. Power in the alpha and theta frequency band was highest after dexchlorpheniramine and lowest after lorazepam. Compared to placebo, alpha power was significantly increased following dexchlorpheniramine $(F(1,16)=11.4, p<0.01)$, and decreased following lorazepam $(F(1,16)=17.1, p<0.01)$. For theta power, the differences from placebo were not significant. However, post-hoc analysis showed that theta power was significantly lower after lorazepam as compared to dexchlorpheniramine $(F(1,16)=6.4, p<0.02)$. There was a significant difference between electrodes in the theta frequency band $(F(2,15)=$ 27.4, $p<0.01)$. The theta power was lower at the $\mathrm{Pz}$ as compared with $\mathrm{Fz}(\mathrm{F}(1,16)=20.0, p<0.01)$ and $\mathrm{Cz}$ electrodes $(F(1,16)=57.8, p<0.01)$. There were no differences between electrodes in the alpha frequency band. There were no significant interactions between Electrodes and Treatments in alpha and theta power bands, indicating that the effects of treatments did not differ between the $\mathrm{Fz}, \mathrm{Cz}$ and $\mathrm{Pz}$ electrode sites. Power in the beta and delta frequency bands did not differ significantly between treatments (Table 3).

\subsection{Effect sizes}

To dissociate the treatment effects on arousal and memory, effect sizes of dexchlorpheniramine and lorazepam for all dependent variables were calculated and are presented in Table 4.

The effect sizes of dexchlorpheniramine on measures of memory from the WLT-30 range from 0.03 to 0.24 . The effect sizes of lorazepam range from 0.40 to 0.85 , and are much larger as compared to dexchlorpheniramine.

The effect sizes of dexchlorpheniramine on accuracy derived from the n-back task were smaller than the effect sizes of lorazepam on this measure. Effect sizes of dexchlorpheniramine and lorazepam ranged from -0.01 to 0.17 and from 0.07 to 0.64 respectively. In addition, the 
Table 3 Mean $\left( \pm\right.$ SEM) absolute power $\left(\mu \mathrm{V}^{2}\right)$ of the delta $(1-4 \mathrm{~Hz})$, theta $(4-8 \mathrm{~Hz})$, alpha $(8-12 \mathrm{~Hz})$ and beta $(13-30 \mathrm{~Hz})$ frequency bands for each electrode and after treatment with dexchlorpheniramine $4 \mathrm{mg}$ (D4), lorazepam $1 \mathrm{mg}$ (L1).

\begin{tabular}{|c|c|c|c|c|c|c|c|}
\hline & & \multirow[t]{2}{*}{ Placebo } & \multirow{2}{*}{$\begin{array}{l}\text { Dexchlorpheniramine } \\
4 \mathrm{mg}\end{array}$} & \multirow{2}{*}{$\begin{array}{l}\text { Lorazepam } \\
1 \mathrm{mg}\end{array}$} & \multirow{2}{*}{$\frac{\text { Main effect of treatment }}{p}$} & \multirow{2}{*}{$\frac{\text { D4 mg vs. placebo }}{p}$} & \multirow{2}{*}{$\begin{array}{l}\mathrm{L} 1 \mathrm{mg} \text { vs. placebo } \\
\mathrm{p}\end{array}$} \\
\hline & & & & & & & \\
\hline \multirow[t]{4}{*}{ Delta power } & & & & & 0.667 & 0.582 & 0.593 \\
\hline & $\mathrm{Fz}$ & $9.7(0.8)$ & $9.3(0.6)$ & $10.7(1.1)$ & & & \\
\hline & $\mathrm{Cz}$ & $10.1(0.6)$ & $9.9(0.7)$ & $10.6(0.9)$ & & & \\
\hline & $\mathrm{Pz}$ & $9.6(0.6)$ & $9.3(0.6)$ & $9.1(0.8)$ & & & \\
\hline \multirow[t]{4}{*}{ Theta power } & & & & & 0.076 & 0.128 & 0.206 \\
\hline & $\mathrm{Fz}$ & $7.1(0.7)$ & $7.5(0.7)$ & $7.0(0.6)$ & & & \\
\hline & $\mathrm{Cz}$ & $7.3(0.7)$ & $7.7(0.7)$ & $6.9(0.6)$ & & & \\
\hline & $\mathrm{Pz}$ & $5.8(0.6)$ & $6.2(0.6)$ & $5.3(0.5)$ & & & \\
\hline \multirow[t]{4}{*}{ Alpha power } & & & & & 0.001 & 0.004 & 0.001 \\
\hline & $\mathrm{Fz}$ & $5.8(0.8)$ & $7.4(1.2)$ & $4.4(0.8)$ & & & \\
\hline & $\mathrm{Cz}$ & $6.9(1.2)$ & 8.7 (1.6) & $4.8(1.0)$ & & & \\
\hline & $\mathrm{Pz}$ & $8.7(2.1)$ & $11.1(2.8)$ & $5.4(1.6)$ & & & \\
\hline \multirow[t]{4}{*}{ Beta power } & & & & & 0.202 & 0.108 & 0.357 \\
\hline & $\mathrm{Fz}$ & $1.2(0.1)$ & $1.4(0.1)$ & $1.3(0.1)$ & & & \\
\hline & $\mathrm{Cz}$ & $1.3(0.1)$ & $1.6(0.2)$ & $1.5(0.2)$ & & & \\
\hline & $\mathrm{Pz}$ & $1.3(0.1)$ & $1.4(0.1)$ & $1.3(0.1)$ & & & \\
\hline
\end{tabular}

Table 4 Effect sizes of dexchlorpheniramine $4 \mathrm{mg}$ (D4) and lorazepam $1 \mathrm{mg}$ (D1) on electrophysiological and behavioural measures of word learning, $n$-back performance and arousal. The power in the frequency bands were averaged over electrodes ( $\mathrm{Fz}, \mathrm{Cz}$ and $\mathrm{Pz}$ ). An asterisk (*) indicates a significant difference as compared with placebo. Lorazepam impaired performance on the $n$-back task, but the effects were not analyzed per memory load.

\begin{tabular}{|c|c|c|c|c|}
\hline Task & Measure & & D4 & L1 \\
\hline \multicolumn{5}{|l|}{ Word learning task } \\
\hline & Immediate recall 1 & & 0.16 & $0.61^{*}$ \\
\hline & Immediate recall 2 & & -0.09 & $0.54^{*}$ \\
\hline & Immediate recall 3 & & 0.03 & $0.62^{*}$ \\
\hline & Delayed recall & & -0.01 & $0.68^{*}$ \\
\hline & Relative recall & & 0.07 & 0.40 \\
\hline & Recognition speed & & 0.01 & $0.84^{*}$ \\
\hline & Recognition accuracy & & 0.24 & $0.85^{*}$ \\
\hline & WLT-P300 amplitude & & 0.17 & $0.57^{*}$ \\
\hline \multirow[t]{13}{*}{ N-back } & & & & * \\
\hline & Accuracy & 0-back & 0.17 & 0.44 \\
\hline & & 1-back & -0.01 & 0.07 \\
\hline & & 2-back & 0.14 & 0.62 \\
\hline & & 3-back & 0.12 & $\begin{array}{l}0.64 \\
*\end{array}$ \\
\hline & Reaction time & 0-back & 0.26 & 0.80 \\
\hline & & 1-back & 0.27 & 0.66 \\
\hline & & 2-back & 0.08 & 0.72 \\
\hline & & 3-back & 0.17 & 0.42 \\
\hline & Nback-P300 amplitude & 0-back & -0.08 & 0.02 \\
\hline & & 1-back & 0.09 & 0.12 \\
\hline & & 2-back & 0.54 & 0.38 \\
\hline & & 3-back & 0.13 & -0.09 \\
\hline Subjective alertness & & & $-0.86^{*}$ & $-1.24^{*}$ \\
\hline \multicolumn{5}{|l|}{ Frequency band power } \\
\hline & Delta & & 0.31 & 0.30 \\
\hline & Theta & & 0.13 & 0.31 \\
\hline & Alpha & & $-0.16^{*}$ & $0.41^{*}$ \\
\hline & Beta & & -0.33 & 0.14 \\
\hline
\end{tabular}


effect sizes of lorazepam on reaction time in the n-back task were much larger than the effect sizes of dexchlorpheniramine. Effect sizes of lorazepam on reaction time ranged from 0.42 to 0.80 , while the effect sizes of dexchlorpheniramine ranged from 0.08 to 0.27 . In contrast, the effect sizes of both treatments on the nback-P300 were comparable. The effect sizes of dexchlorpheniramine ranged from -0.08 to 0.54 and of lorazepam from -0.09 to 0.38 .

Lorazepam also showed a larger effect size on subjective alertness $(E S=-1.24)$ as compared to dexchlorpheniramine $(E S=-0.86)$. The absolute effect sizes of both treatments on frequency band power were comparable (i.e. between 0.13 and 0.41). However, lorazepam affected the alpha frequency band more $(E S=0.41)$ as compared to dexchlorpheniramine $(E S=-0.16)$, albeit in different directions.

\section{Discussion}

This study was designed to assess effects of an antihistamine on memory functioning as measured by performance and electrocortical activity. Dexchlorpheniramine $4 \mathrm{mg}$ showed no effects on memory performance, while it did increase objectively and subjectively measured signs of sedation. This is in line with results from a previous study, showing that dexchlorpheniramine $4 \mathrm{mg}$ has significant effects on psychomotor performance, and supports the conclusion that $\mathrm{H}_{1}$ blockade has no effects on human memory performance (Van Ruitenbeek et al., 2008).

In contrast, results clearly showed that the active control, lorazepam $1 \mathrm{mg}$, significantly impaired recall and recognition of words and decreased the WLT-P300 amplitude during encoding. In addition, lorazepam impaired speed and accuracy of working memory, but did not affect the nbackP300. Lorazepam also induced objectively and subjectively measured sedation, indicating that measures and procedures were sufficiently sensitive.

Most studies that assessed lorazepam's effects on alertness and cognition have used a relatively high dose of $2 \mathrm{mg}$, that is well known to produce anterograde amnesia and marked feelings of sedation (Curran et al., 1998; Mintzer and Griffiths, 2003; Vermeeren et al., 1995). As lorazepam $1 \mathrm{mg}$ had also been found to produce objective impairment in memory tests, even without significant feelings of sedation (Mintzer and Griffiths, 2005), this lower dose was considered more suitable comparator for dexchlorpheniramine in the present study, and better to maintain blinding of the study. The sedative effects of lorazepam $1 \mathrm{mg}$, as measured by alpha and theta power and subjects' feelings of alertness in our study, were found to be more pronounced than those of dexchlorpheniramine $4 \mathrm{mg}$, however. Nonetheless, the difference in effect sizes between lorazepam and dexchlorpheniramine on memory related variables was even larger than the difference in sedative effects. So, although lorazepam produced slightly more sedation than dexchlorpheniramine, this cannot explain the absence of dexchlorpheniramine effects on memory.

Lorazepam impaired immediate recall but not relative recall, suggesting that the rate of forgetting is not affected. Rammsayer et al. (2000) also found similar forget rates after administration of midazolam and placebo. In contrast, psychophysiological measurements showed that the WLT-
P300 amplitude during encoding was significantly reduced after lorazepam administration. It has been shown that larger P300 amplitudes during encoding predict better recall (Friedman and Johnson, 2000). The lack of effect of dexchlorpheniramine on the WLT-P300 amplitude in the present study is in line with the finding that dexchlorpheniramine did not affect immediate and delayed recall. In addition to information encoding the P300 is also regarded as being involved in updating of memory (Polich, 2007). However, the treatments did not affect the amplitude of the nback-P300. As there were only 11 target trials per $\mathrm{N}$ back these may have been insufficient to detect treatment effects. Nevertheless, increased memory load did decrease the nback-P300 amplitude, indicating that the measure was sufficiently sensitive to detect changes in memory processing.

The question arises why $\mathrm{H}_{1}$-antagonism does not seem to impair memory functions in humans, as this contradicts findings from animal studies (Passani et al., 2000). The conclusion that $\mathrm{H}_{1}$-receptors are involved in memory functioning is supported by results from animal studies which decreased histaminergic activity by using different histaminergic manipulations (Alvarez and Ruarte, 2004; Dai et al., 2007; Garbarg et al., 1992; Miyazaki et al., 1995), whereas enhancement of histaminergic activity using $\mathrm{H}_{3}$ antagonists was found to improve memory performance (Wijtmans et al., 2007). In addition, $\mathrm{H}_{1}$-receptors are found in the prefrontal and temporal cortices in humans considered important for memory functioning (Tashiro et al., 2002; Yanai et al., 1992) and in the hippocampus in rats (Palacios et al., 1981). These results lead to the expectation that $\mathrm{H}_{1}$-antagonism impairs memory in humans.

It may be that the effects of $\mathrm{H}_{1}$ and $\mathrm{H}_{3}$ compounds in animals cannot be directly translated to man. A reason for this may lie in the use of mnemonic strategies and associated brain structures. Memory performance in rats is highly dependent on the hippocampus, while humans are able to use more cognitive strategies (e.g. use of language) and, therefore, other brain structures. This may result in a higher sensitivity of rats for effects on memory. In addition, there are differences between species in receptor affinities, as it has been reported that $\mathrm{H}_{3}$-receptor affinities for some compounds are lower in humans than in animals (Parsons and Ganellin, 2006). As $\mathrm{H}_{3}$ compounds are still hardly available for studies in man, the question whether the translation regarding these compounds can be made, is yet to be answered.

The $\mathrm{H}_{3}$-antagonists may still be able to improve memory performance, even if $\mathrm{H}_{1}$ - receptors do not play a role in human memory. $\mathrm{H}_{3}$-receptors may play a relatively large role as heteroreceptors in memory functioning (Passani et al., 2004). For example, $\mathrm{H}_{3}$-receptor compounds are able to modulate cholinergic activity in the cortex (Blandina et al., 2004), which have been suggested to mediate H3-antagonist's effects on memory (Passani et al., 2000). This hypothesis is supported by the finding that bilateral lesions of the tuberomammillary nucleus produced facilitation of learning (Klapdor et al., 1994). The lesions may lead to decreased tonic activation of $\mathrm{H}_{3}$-heteroreceptors and thus less inhibition of other neurotransmitters (e.g. acetylcholine). Therefore, blocking $\mathrm{H}_{3}$-receptor activity may disinhibit neurotransmitter activity other than histamine activity. 
In agreement with the results from the present study, many studies found increased subjective drowsiness after intake of lorazepam $1 \mathrm{mg}$ [e.g. (Bond and Lader, 1988; Hanks et al., 1995; Preston et al., 1988)] and dexchlorpheniramine $4 \mathrm{mg}$ [e.g.(Van Ruitenbeek et al., 2008)]. Shifts of the power in the EEG frequency spectrum from an alert waking state to mild sedation are usually characterized by increases in theta and alpha power (Galliaud et al., 2008; Griffiths et al., 1991) and decreases beta power. In accordance, dexchlorpheniramine $4 \mathrm{mg}$ produced a significant increase in alpha power in our study. Changes in power of lower frequencies following use of mildly sedating antihistamines have also been found by Ramaekers et al. (1992) using cetirizine $10 \mathrm{mg}$. It must be stated that most studies measure EEG frequencies in a resting state, in the present study EEG was measured while words were presented to the subjects on a computer screen. The expectation of the appearance of a stimulus has been shown to reduce power of frequencies between 0 and $42.9 \mathrm{~Hz}$ (Gomez et al., 2004), possibly making drug effects more difficult to detect. Nevertheless, in the study by Ramaekers et al. (1992) the significant increase in slow alpha frequency $(8-10 \mathrm{~Hz})$ after cetirizine $10 \mathrm{mg}$ was also measured during driving performance. This suggests that the decrease in power across the frequency spectrum does not prevent druginduced increases in alpha activity.

In contrast to the effects of dexchlorpheniramine, lorazepam decreased power in the alpha frequency band. Benzodiazepines like lorazepam are well known to be potent suppressors of cortical EEG alpha rhythm (Berchou et al., 1986; Ebert et al., 2000; Schreckenberger et al., 2004), which may be related to a reduction in thalamic activity. Schreckenberger et al. (2004) found that lorazepam induced changes in alpha power to exclusively correlate with thalamic metabolism. They argue that decreased occipital cortical input to the thalamus results in desynchronization of thalamic output and, therefore, decreased oscillatory alpha activity.

In conclusion, the hypothesis that antihistamines do not affect memory performance is supported by our data. Both the EEG data and the subjective measure of drowsiness indicated that subjects were sedated after the administration of dexchlorpheniramine $4 \mathrm{mg}$. Effects on speed and accuracy of working memory, and the learning and recall of words were not observed. In contrast, the active control drug lorazepam clearly affected measures of encoding and memory performance. It is concluded that $\mathrm{H}_{1}$-receptor activation is not crucial for human memory functioning.

\section{Role of the funding source}

The study was paid by, carried out at, and only reported within Maastricht University. Any decision was entirely the author's.

\section{Contributors}

P van Ruitenbeek, A Vermeeren and W.J. Riedel designed the study and wrote the protocol. P. van Ruitenbeek managed the literature searches and analyses, undertook the statistical analyses and wrote the first draft of the manuscript. Subsequent revisions were made by all authors and have approved the final manuscript.

\section{Conflict of interest}

A. Vermeeren has received grants from GlaxoSmithKline, HoffmanLaRoche and Pierre Fabre. At times during the study, W.J. Riedel has been employed by GlaxoSmithKline R\&D, Cambridge, UK and is now employed by Hoffman-LaRoche R\&D, Basel, Switzerland while remaining affiliated to Maastricht University. All authors declare they have no conflict of interest.

\section{Acknowledgements}

The authors would like to thank J. Conjaerts, M.Sc. and S. van der Vleuten M.Sc. for their contribution to the data collection, C. van Leeuwen, MD for the medical supervision and Dr. G. van Breukelen for the advice on statistical analysis and I. Brauers for the logistic work.

\section{References}

Acevedo, S.F., Ohtsu, H., Benice, T.S., Rizk-Jackson, A., Raber, J., 2006. Age-dependent measures of anxiety and cognition in male histidine decarboxylase knockout (Hdc(-/-)) mice. Brain Res. 1071, 113-123.

Alvarez, E.O., Ruarte, M.B., 2004. Glutamic acid and histaminesensitive neurons in the ventral hippocampus and the basolateral amygdala of the rat: functional interaction on memory and learning processes. Behav. Brain Res. 152, 209-219.

Bacciottini, L., Passani, M.B., Mannaioni, P.F., Blandina, P., 2001. Interactions between histaminergic and cholinergic systems in learning and memory. Behav. Brain Res. 124, 183-194.

Berchou, R., Chayasirisobhon, S., Green, V., Mason, K., 1986. The pharmacodynamic properties of lorazepam and methylphenidate drugs on event-related potentials and power spectral analysis in normal subjects. Clin. Electroencephalogr. 17, 176-180.

Blandina, P., Efoudebe, M., Cenni, G., Mannaioni, P., Passani, M.B., 2004. Acetylcholine, histamine, and cognition: two sides of the same coin. Learn Mem. 11, 1-8.

Bond, A., Lader, M., 1974. The use of analogue scales in rating subjective feelings. Br. J. Med. Psychol. 47, 211-218.

Bond, A., Lader, M., 1988. Differential effects of oxazepam and lorazepam on aggressive responding. Psychopharmacology (Berl) 95, 369-373.

Borbely, A.A., 1982. A two process model of sleep regulation. Hum. Neurobiol. 1, 195-204.

Braver, T.S., Cohen, J.D., Nystrom, L.E., Jonides, J., Smith, E.E., Noll, D.C., 1997. A parametric study of prefrontal cortex involvement in human working memory. Neuroimage 5, 49-62.

Busto, U.E., Kaplan, H.L., Wright, C.E., Gomez-Mancilla, B., Zawertailo, L., Greenblatt, D.J., Sellers, E.M., 2000. A comparative pharmacokinetic and dynamic evaluation of alprazolam sustained-release, bromazepam, and lorazepam. J. Clin. Psychopharmacol. 20, 628-635.

Curran, H.V., 2000. Psychopharmacological perspectives on memory. In: Tulving, E., Craik, F.I.M. (Eds.), The Oxford Handbook of Memory. Oxford University Press, Oxford.

Curran, H.V., Pooviboonsuk, P., Dalton, J.A., Lader, M.H., 1998. Differentiating the effects of centrally acting drugs on arousal and memory: an event-related potential study of scopolamine, lorazepam and diphenhydramine. Psychopharmacology (Berl) 135, 27-36.

Dai, H., Kaneko, K., Kato, H., Fujii, S., Jing, Y., Xu, A., Sakurai, E., Kato, M., Okamura, N., Kuramasu, A., Yanai, K., 2007. Selective cognitive dysfunction in mice lacking histamine $\mathrm{H} 1$ and $\mathrm{H} 2$ receptors. Neurosci. Res. 57, 306-313.

De Brabander, A., Deberdt, W., 1990. Effect of hydroxyzine on attention and memory. Hum. Psychopharmacol. 5, 357-362. 
Dunlap, W.P., Cortina, J.M., Vaslow, J.B., Burke, M.J., 1996. Metaanalysis of experiments with matched groups or repeated measures designs. Psychological Methods 1, 170-177.

Ebert, U., Oertel, R., Kirch, W., 2000. Physostigmine reversal of midazolam-induced electroencephalographic changes in healthy subjects. Clin. Pharmacol. Ther. 67, 538-548.

File, S.E., Lister, R.G., 1982. Do lorazeam-induced deficits in learning result from impaired rehearsal, reduced motivation or increased sedation? Br. J. Clin. Pharmacol. 14, 545-550.

Friedman, D., Johnson Jr., R., 2000. Event-related potential (ERP) studies of memory encoding and retrieval: a selective review. Microsc. Res. Tech. 51, 6-28.

Galliaud, E., Taillard, J., Sagaspe, P., Valtat, C., Bioulac, B., Philip, P., 2008. Sharp and sleepy: evidence for dissociation between sleep pressure and nocturnal performance. J. Sleep Res. 17, 11-15.

Garbarg, M., Arrang, J.M., Rouleau, A., Ligneau, X., Tuong, M.D., Schwartz, J.C., Ganellin, C.R., 1992. S-[2-(4-imidazolyl)ethyl] isothiourea, a highly specific and potent histamine $\mathrm{H} 3$ receptor agonist. J. Pharmacol. Exp. Ther. 263, 304-310.

Gevins, A., Smith, M.E., McEvoy, L.K., 2002. Tracking the cognitive pharmacodynamics of psychoactive substances with combinations of behavioral and neurophysiological measures. Neuropsychopharmacology 26, 27-39.

Gomez, C.M., Vaquero, E., Lopez-Mendoza, D., Gonzalez-Rosa, J., Vazquez-Marrufo, M., 2004. Reduction of EEG power during expectancy periods in humans. Acta Neurobiol. Exp. (Wars) 64, 143-151.

Greenblatt, D.J., 1981. Clinical pharmacokinetics of oxazepam and lorazepam. Clin. Pharmacokinet. 6, 89-105.

Greenblatt, D.J., von Moltke, L.L., Harmatz, J.S., Durol, A.L., Daily, J.P., Graf, J.A., Mertzanis, P., Hoffman, J.L., Shader, R.I., 2000. Differential impairment of triazolam and zolpidem clearance by ritonavir. J. Acquir. Immune. Defic. Syndr. 24, 129-136.

Griffiths, M.J., Preece, A.W., Green, J.L., 1991. Monitoring sedation levels by EEG spectral analysis. Anesth. Prog. 38, 227-231.

Hanks, G.W., O'Neill, W.M., Simpson, P., Wesnes, K., 1995. The cognitive and psychomotor effects of opioid analgesics. II. A randomized controlled trial of single doses of morphine, lorazepam and placebo in healthy subjects. Eur. J. Clin. Pharmacol. 48, 455-460.

Hindmarch, Shamsi, Z., 2001. The effects of single and repeated administration of ebastine on cognition and psychomotor performance in comparison to triprolidine and placebo in healthy volunteers. Curr. Med. Res. Opin. 17, 273-281.

Jasper, H.H., 1957. The ten-twenty electrode system of the international federation. Electroencephalogr. Clin. Neurophysiol. 10, 371-375.

Klapdor, K., Hasenohrl, R.U., Huston, J.P., 1994. Facilitation of learning in adult and aged rats following bilateral lesions of the tuberomammillary nucleus region. Behav. Brain Res. 61, 113-116.

Mintzer, M.Z., Griffiths, R.R., 2003. Lorazepam and scopolamine: a single-dose comparison of effects on human memory and attentional processes. Exp. Clin. Psychopharmacol. 11, 56-72.

Mintzer, M.Z., Griffiths, R.R., 2005. Drugs, memory, and metamemory: a dose-effect study with lorazepam and scopolamine. Exp. Clin. Psychopharmacol. 13, 336-347.

Miyazaki, S., Imaizumi, M., Onodera, K., 1995. Ameliorating effects of histidine on scopolamine-induced learning deficits using an elevated plus-maze test in mice. Life Sci. 56, 1563-1570.

Otten, L.J., Donchin, E., 2000. Relationship between P300 amplitude and subsequent recall for distinctive events: dependence on type of distinctiveness attribute. Psychophysiology 37, 644-661.

Palacios, J.M., Wamsley, J.K., Kuhar, M.J., 1981. The distribution of histamine H1-receptors in the rat brain: an autoradiographic study. Neuroscience 6, 15-37.

Parsons, M.E., Ganellin, C.R., 2006. Histamine and its receptors. Br. J. Pharmacol. 147 (Suppl 1), S127-S135.
Passani, M.B., Bacciottini, L., Mannaioni, P.F., Blandina, P., 2000. Central histaminergic system and cognition. Neurosci. Biobehav. Rev. 24, 107-113.

Passani, M.B., Lin, J.S., Hancock, A., Crochet, S., Blandina, P., 2004. The histamine $\mathrm{H} 3$ receptor as a novel therapeutic target for cognitive and sleep disorders. Trends Pharmacol. Sci. 25, 618-625.

Patat, A., Gram, L.F., Dubruc, C., Brohier, S., Cabanis, M.J., Rosenzweig, P., 1994. Effects of mizolastine, a new antihistamine, on psychomotor performance and memory in elderly subjects. Int. Clin. Psychopharmacol. 9, 101-108.

Polich, J., 2007. Updating P300: an integrative theory of P3a and P3b. Clin. Neurophysiol. 118, 2128-2148.

Preston, G.C., Broks, P., Traub, M., Ward, C., Poppleton, P., Stahl, S.M., 1988. Effects of lorazepam on memory, attention and sedation in man. Psychopharmacology (Berl) 95, 208-215.

Ramaekers, J.G., Uiterwijk, M.M., O'Hanlon, J.F., 1992. Effects of loratadine and cetirizine on actual driving and psychometric test performance, and EEG during driving. Eur. J. Clin. Pharmacol. 42, 363-369.

Rammsayer, T.H., Rodewald, S., Groh, D., 2000. Dopamine-antagonistic, anticholinergic, and GABAergic effects on declarative and procedural memory functions. Brain Res. Cogn. Brain Res. 9, 61-71.

Rey, A., 1964. L'exam psychologique dans les cas d'encéphalopathie traumatique. Presses Universitaires de France.

Riedel, W.J., Klaassen, T., Deutz, N.E., van Someren, A., van Praag, H.M., 1999. Tryptophan depletion in normal volunteers produces selective impairment in memory consolidation. Psychopharmacology (Berl) 141, 362-369.

Riedel, W.J., Van Praag, H., 1995. Avoiding and managing anticholinergic effects of antidepressants. CNS Drugs 3, 245-259.

Saletu, B., Grunberger, J., Sieghart, W., 1986. Pharmaco-EEG, behavioural methods and blood levels in the comparison of temazepam and flunitrazepam. Acta Psychiatr. Scand. Suppl. 332, 67-94.

Sannita, W.G., Crimi, E., Riela, S., Rosadini, G., Brusasco, V., 1996. Cutaneous antihistaminic action of cetirizine and dose-related EEG concomitants of sedation in man. Eur. J. Pharmacol. 300, $33-41$.

Schreckenberger, M., Lange-Asschenfeldt, C., Lochmann, M., Mann, K., Siessmeier, T., Buchholz, H.G., Bartenstein, P., Grunder, G., 2004. The thalamus as the generator and modulator of EEG alpha rhythm: a combined PET/EEG study with lorazepam challenge in humans. Neuroimage 22, 637-644.

Semlitsch, H.V., Anderer, P., Schuster, P., Presslich, O., 1986. A solution for reliable and valid reduction of ocular artifacts, applied to the P300 ERP. Psychophysiology 23, 695-703.

Simons, F.E., Reggin, J.D., Roberts, J.R., Simons, K.J., 1994. Benefit/risk ratio of the antihistamines (H1-receptor antagonists) terfenadine and chlorpheniramine in children. J. Pediatr. 124, 979-983.

Tashiro, M., Mochizuki, H., Iwabuchi, K., Sakurada, Y., Itoh, M., Watanabe, T., Yanai, K., 2002. Roles of histamine in regulation of arousal and cognition: functional neuroimaging of histamine $\mathrm{H} 1$ receptors in human brain. Life Sci. 72, 409-414.

Theunissen, E.L., Jonkman, L.M., Kuypers, K.P., Ramaekers, J.G., 2006. A combined neurophysiological and behavioural study into the stimulating effects of fexofenadine on performance. J. Psychopharmacol. 20, 496-505.

Theunissen, E.L., Vermeeren, A., van Oers, A.C., van Maris, I., Ramaekers, J.G., 2004. A dose-ranging study of the effects of mequitazine on actual driving, memory and psychomotor performance as compared to dexchlorpheniramine, cetirizine and placebo. Clin. Exp. Allergy 34, 250-258.

Turner, C., Handford, A.D., Nicholson, A.N., 2006. Sedation and memory: studies with a histamine $\mathrm{H}-1$ receptor antagonist. J. Psychopharmacol. 20, 506-517. 
Van Ruitenbeek, P., Vermeeren, A., Riedel, W.J., 2008. Histamine $\mathrm{H} 1$-receptor blockade in humans affects psychomotor performance but not memory. J. Psychopharmacol. 22, 663-672.

Veltman, D.J., Rombouts, S.A., Dolan, R.J., 2003. Maintenance versus manipulation in verbal working memory revisited: an fMRI study. Neuroimage 18, 247-256.

Vermeeren, A., Jackson, J.L., Muntjewerff, N.D., Quint, P.J., Harrison, E.M., O'Hanlon, J.F., 1995. Comparison of acute alprazolam $(0.25,0.50$ and $1.0 \mathrm{mg})$ effects versus those of lorazepam $2 \mathrm{mg}$ and placebo on memory in healthy volunteers using laboratory and telephone tests. Psychopharmacology (Berl) 118, 1-9.

Verster, J.C., Volkerts, E.R., van Oosterwijck, A.W., Aarab, M., Bijtjes, S.I., De Weert, A.M., Eijken, E.J., Verbaten, M.N., 2003. Acute and subchronic effects of levocetirizine and diphenhydramine on memory functioning, psychomotor performance, and mood. J. Allergy Clin. Immunol. 111, 623-627.

Volkerts, E.R., Van Willigenburg, A.P., Van Laar, M.W., Maes, R.A., 1992. Does cetirizine belong to the new generation of antihistamines? An investigation into its acute and subchronic effects on highway driving, psychometric test performance and daytime sleepiness. Hum. Psychopharm. Clin. Exp. 7, 227-238.

Vuurman, E.F., Uiterwijk, M.M., Rosenzweig, P., O'Hanlon, J.F., 1994. Effects of mizolastine and clemastine on actual driving and psychomotor performance in healthy volunteers. Eur. J. Clin. Pharmacol. 47, 253-259.
Vuurman, E.F., Rikken, G.H., Muntjewerff, N.D., de Halleux, F., Ramaekers, J.G., 2004. Effects of desloratadine, diphenhydramine, and placebo on driving performance and psychomotor performance measurements. Eur. J. Clin. Pharmacol. 60, 307-313.

Watter, S., Geffen, G.M., Geffen, L.B., 2001. The n-back as a dualtask: P300 morphology under divided attention. Psychophysiology 38, 998-1003.

Wiech, N.L., Martin, J.S., 1982. Absence of an effect of terfenadine on guinea pig brain histamine $\mathrm{H} 1$-receptors in vivo determined by receptor binding techniques. Arzneimittelforschung 32, 1167-1170.

Wijtmans, M., Leurs, R., de Esch, I., 2007. Histamine H3 receptor ligands break ground in a remarkable plethora of therapeutic areas. Expert Opin. Investig. Drugs. 16, 967-985.

World-Medical-Association, 1964. World Medical Association Declaration of Helsinki: Ethical principles for medical research involving human subjects.

Yanai, K., Watanabe, T., Yokoyama, H., Meguro, K., Hatazawa, J., Itoh, M., Iwata, R., Ishiwata, K., Takahashi, T., Ido, T., 1992. Histamine $\mathrm{H} 1$ receptors in human brain visualized in vivo by [11C] doxepin and positron emission tomography. Neurosci. Lett. 137, 145-148.

Zarrindast, M.R., Parsaei, L., Ahmadi, S., 2008. Repeated administration of histamine improves memory retrieval of inhibitory avoidance by lithium in mice. Pharmacology 81, 187-194. 